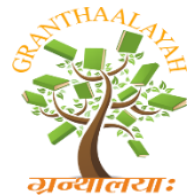

INTERNATIONAL JOURNAL OF RE
GRANTHAALAYAH A knowledge Repository

Science

\title{
INSECT POLLINATORS DIVERSITY IN AVOCADO ORCHARD DURING FLOWERING PERIOD IN LUSHOTO DISTRICT TANZANIA
}

\author{
Christopher L Materu *1 \\ ${ }^{*}$ P O Box 6226, Dar Es Salaam Tanzania
}

\begin{abstract}
Insect pollinator diversity is key to ensuring adequate fruit yields within avocado orchards. Bee and non-bee insect species in avocado growing areas worldwide, has been considered as potential pollinators. Despite of this information in Tanzania there has been little research into which pollinator insect species diversity visit avocado flowers during flowering season. The study was conducted at Jaegetal avocado orchard from 450 trees of Hass variety planted at spacing of 10m $\mathrm{x}$ $10 \mathrm{~m}$. Sample size was 10 trees were used to generate pollinator's population estimates. The orchard is located at S04 47'41.7' and E038 $13^{\prime} 11.8^{\prime \prime}$. Sweep net, forceps and aspirator were used to estimate pollinator's diversity during avocado production season 2018/19.

The results showed a total of 115 individuals were sampled and honey bees were more abundant flower visitors representing $60 \%$ of all insects recorded. The second species observed included the stingless bee representing (26\%), followed by tachnid fly $(6 \%)$ and hoverfly $(6 \%)$. The least species in abundance was ants $(1 \%)$ and wasps $(1 \%)$. Mean population comparison there was significant differences $\mathrm{P}<0.005$.Understanding pollinators species diversity interaction between honey bee and other flower visitor's abundances within and outside orchards could assist in improving pollination recommendations in avocado growing areas.
\end{abstract}

Keywords: Avocado; Pollinator's Abundance.

Cite This Article: Christopher L Materu. (2019). "INSECT POLLINATORS DIVERSITY IN AVOCADO ORCHARD DURING FLOWERING PERIOD IN LUSHOTO DISTRICT TANZANIA." International Journal of Research - Granthaalayah, 7(12), 20-24. https://doi.org/10.29121/granthaalayah.v7.i12.2019.296.

\section{Introduction}

Avocado (Persea americana), native to CentralAmerica and Mexico, is an evergreen subtropical fruiting tree grown for commercially in the tropics (Evans et al., 2010). Insect pollination has been shown to beessential for fruit production (Ish-Am \& Lahav 2011). A wide range of insect pollinators has been reported worldwide including bees, wasps (Hymenoptera) and flies (Diptera) (Kevan \& Baker, 1983; Perez-Balam et al., 2012). Pollinators including honeybee, wild pollinators requires diverse plants to provide sustainable biological insurance for pollination activity in avocado orchard (Ssymank et al., 2008). 
Honey bees as a native pollinator pollinate more than $80 \%$ of cultivated and non-cultivated plants. Enhancing bio diversity is an important to support stronger and more resilient ecosystems. The health of pollinator population, has, been impacted over recent decades by a variety of factors the loss, degradation, and fragmentation of habitat; diminished quantity and quality of food sources; reduced availability of sites for mating, nesting, migration; exposure to pesticides, increased adverse effects from pathogens, arthropod pests and parasites.

Therefore, good knowledge on alternate food sources and nesting sites for pollinators is needed to modify agricultural land-use. Pesticide use has been reported to have negative impact to honey bee and other potential pollinators therefore, protecting of both wild and domesticated wild pollinators is an important in avocado production. Pesticide use in honeybee areas should be applied early morning or late evening when bee population activity is very low.

Pesticide applications in avocado production may include different types of insecticides, fungicides, bactericides, herbicides, and others, each having different toxicity profile and impact on various insect species (Blacquiere et al., 2012). Good pollinator habitat sites suitable for bee foraging are open landscapes with good sun exposure and different types of plants including avocado. Large habitat types ie forest closer to avocado orchard are recommended than smaller and isolated orchard. Natural or artificial forest habitats with a variety of native flowering plants that have overlapping blooming times and that are adapted to local soils and climates are good source of nectar and pollen for pollinators (Black et al., 2007).

Bee health is affected when pesticides area applied to manage threat pests (Biddinger et al., 2013). Various studies showed that pesticide use are not host specific to target organisms, pollute environment and also are harmful to human being (Hooven et al., 2013). It is important to identify pollinator species diversity visiting avocado flowers during full bloom period. Identifying potential pollinators will assist to plan for sustainable enhancement of potential pollinators in avocado production in Tanzania and neighboring countries.

\section{Materials and Methods}

The study area is located at S $04^{\circ} 47^{\prime} 41.7^{\prime \prime}$ and E $038^{\circ} 13^{\prime} 11.8^{\prime \prime}$ in Lushoto district. The insect pollinator's estimation was carried on during the avocado season in September 2018. The size of the orchard is $4.5 \mathrm{ha}$ with a total of 450 trees of Hass variety planted at spacing of $10 \mathrm{~m}$ by $10 \mathrm{~m}$. Two records were collected starting from 11:30AM to 17:00PM by two trained scientists during the study period. Random sampling, visual observations, sweep nets and forceps were used to estimate species diversity of pollinator visiting avocado flowers.

\section{Results}

During the study period honey bees were observed as an important pollinators and their efficiency was due to the large number of forager bees. Frequent foraging on open flowers for a short time indicates there is an efficient pollination. Different plants with different flowering period around avocado orchard enable bees to use little time for pollen and nectar collection. Furthermore, in the forest habitat destruction of the forest for different use lowers plant species diversity. Similarly, it means that changes for forest to other uses it reduce pollinator's activity. Therefore, it is 
recommended to leave weeds hedges or trees for conserving potential pollinators in avocado growing areas.

Avocado requires insect pollination to maximize yields production. Furthermore, findings from this study showed that honey bee or sting bee (Apis mellifera) and non-sting bee (Meliponinae Apidae)as one of the potential pollinators in avocado orchard. Abundance of bee pollinators was high compared to non-bee pollinators indicating that bee has a major role in avocado crop pollination. The results showed that a total of 115 individuals were observed and honey bees were more abundant visitors representing $60 \%$ of all insects recorded. Common pollinators observed included the stingless bee $(26 \%)$, followed by tachnid fly $6 \%$, hoverfly $(6 \%)$ and the least was wasps $(1 \%)$ and ants (1\%) Figure 1.

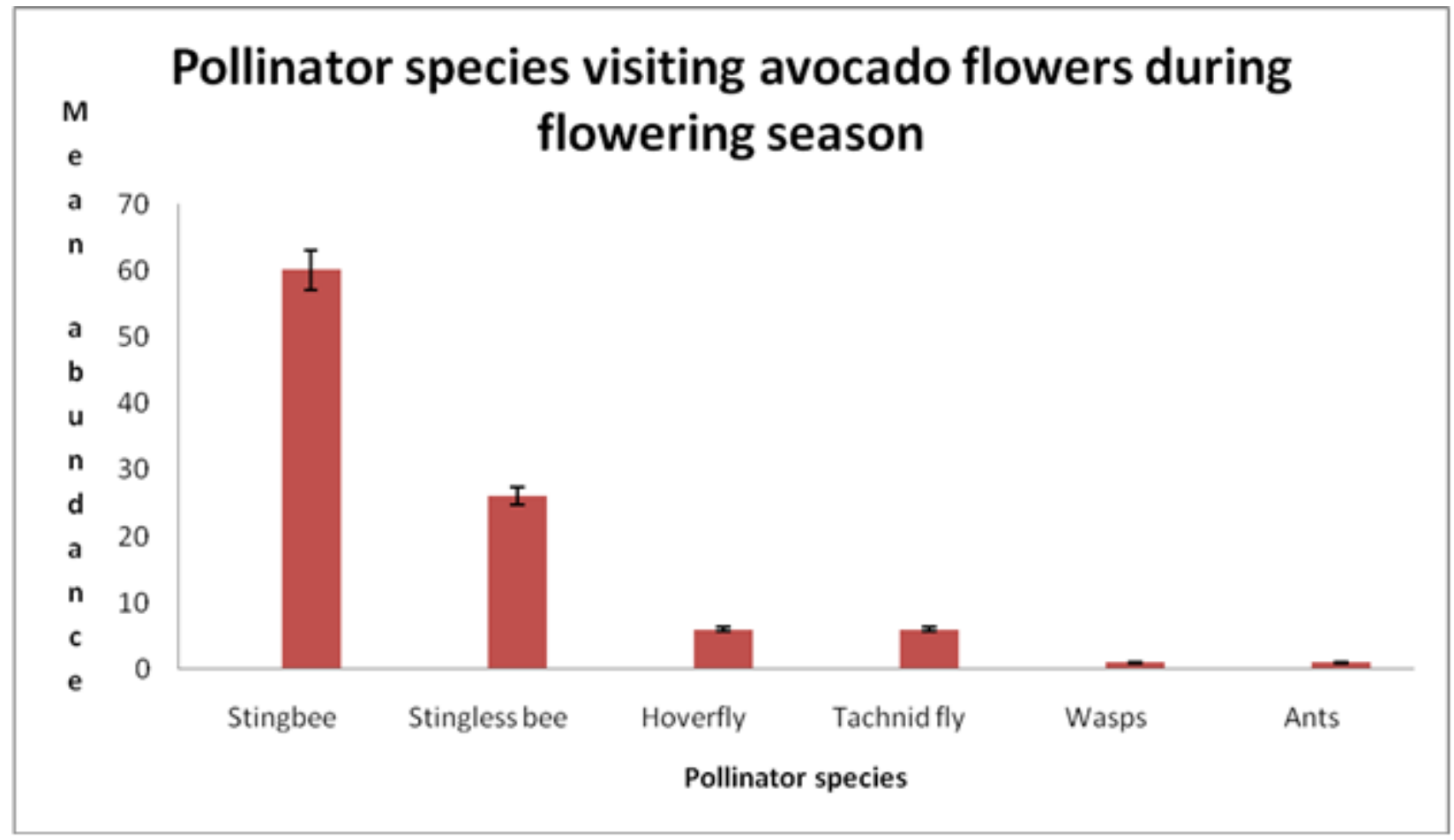

Figure 1: Insects pollinators that were collected from Jaegetal avocado orchard during 2018/2019 season

\section{Results Discussions}

Findings from this work agreed to other studies carried out by Rader et al., (2009), he mentioned that the most effective pollinator species are those occurring in high abundance, actively moving from flower to flower and has a high visitation rate and transferring pollen grains from one tree to another. Efficient insect pollination can be estimated by counting or capture number of pollinator species visiting flowers during the bloom season (Pearce et al., 2012). Furthermore, in avocado growing areas our emphasis was given to honey bee population as a major pollinator (Abrol 2012). Full bloom was observed to attract different insect pollinators (Faegri \& Pijl, 1979). Increase amount of food at a specified time observed to increase number of pollinators visiting avocado flowers, furthermore, increase of insect species diversity will increase pollination efficiency. 


\section{Conclusion}

Farmers are encouraged to plant different tree species or food crops to increase diversity of bee foraging as well as genetic variability in avocado growing areas. Furthermore, it was observed that orchard surrounded by perennial trees, grasses encourage bee visitation to their crops, or to leave part of their land fallow was an important to increase pollinator habitat (Vaughnet al., 2012).

It is good to provide public education to consumers to choose products produced with good pollinator protection standards. This option will encourage conservation bodies in the country to reward honey bee produced from farm practices that preserve pollinator health. Different stakeholders including private sector, NGO can be involved, agricultural input suppliers, food retailers to strengthening capacity on pollinator surveys. Furthermore, to support recovery of endangered pollinator as well as plant species. To conduct regular surveys for pollinators before and after pesticide use is an important activity to measure the side effect caused by pesticides in avocado growing areas.

\section{Acknowledgements}

The research team would like to acknowledge Tanzania Agricultural Research Institute (TARI) Mikocheni for their acceptance to participate in this particular research work, Dr Thomas from International Centre for Insect Physiology and Ecology (ICIPE) for their financial support. Lastly to the pest control staffs and farmers for their commitment during the study period. Without support from this identified team this work wouldn't be possible to be carried out.

\section{References}

[1] Abrol, D. P. 2012. Pollination biology: biodiversity conservation and agricultural production. Springer, New York.

[2] Black, S. H., N. Hodges, M. Vaughan, and M. Shepherd. Pollinators in Natural Areas: A Primer on Habitat Management. Xerces Society for Invertebrate Conservation, 2007. Print

[3] Blacquiere T, Smagghe G, van Gestel CAM, Mommaerts V: Neonicotinoids in bees: a review on concentration, side effects and risk assessment. Ecotoxicology 2012 http:// dx.doi.org/10.1007/s10646-012-0863-x.

[4] Biddinger DJ, Robertson J, Mullin C, Frazier J, Joshi NK, Vaughn M, Ashcraft S: Comparative toxicities and synergism of orchard pesticides to Apismellifera (L.) and Osmiacornifrons (Radoszkowski). PloS One 2013, 8:e72587 http://dx.doi.org/ 10.1371/journal.pone.0072587.

[5] FAEGRI, K.; PIJL, L. VAN DER 1979. The Principies of PollinationEcology. 3111ed. Pergamon Press. Oxford. UK. 244 p.

[6] Hooven LA, Sagili RR, Johansen E: How to Reduce Bee Poisoning from Pesticides. Oregon State University Extension Service. Oregon State University; 2013: PNW 591

[7] Kevan PG, Baker HG (1983) Insects as flower visitors and pollinators. Annual Review of Entomology28: 407-453.

[8] Perez-Balam, J., J. J. G. Quezada-Euan, R. Alfaro-Bates, S. Medina, A.Soro, and R. J. Paxton. 2012. The contribution of honey bees, flies andwasps to avocado (Persea americana) pollination in southern Mexico.J. Pollinat. Ecol. 8: 42-47.

[9] Pearce, A. M., K. M. O’Neill, R. S. Miller, and S. Blodgett. 2012. Diversityof flower visiting bees and their pollen loads on a wildflower seed farm inMontana. J. Kans. Entomol. Soc. 85: 97-108. 
[10] Proceedings VIIWorld Avocado Congress 2011 (Actas VII Congreso Mundial delAguacate 2011). Cairns, Australia.5 - 9 September 2011

[11] Rader, R., W. Edwards, D. A. Wescott, S. A. Cunningham, and B. G.Howlett. 2011. Pollen transport differs among bees and flies in a human modified landscape. Divers. Distrib.17: 519-529.

[12] Ssymank A, Kearns CA, Pape T, Thompson FC (2008) Pollinating flies (Diptera): a major contribution to plant diversity and agricultural production. Biodiversity 9: 86-89.

[13] Vaughn M, Mader E, Guisse J, Goldetz-Dollar J, Borders B, Biddinger D, Gillis J: USDA-NRCS Conservation Cover (327) for Pollinators - Pennsylvania Installation Guide and Job Sheet. 2012: http://www.xerces.org/pollinator-conservation/agriculture/ pollinator-habitat-installation-guides/.

[14] Vaughn M, Mader E, Guisse J, Goldetz-Dollar J, Borders B, Biddinger D, Gillis J: USDA-NRCS Hedgerow Plantings (422) for Pollinators - Pennsylvania Installation Guide and Job Sheet. 2012: http://www.xerces.org/pollinator-conservation/agriculture/ pollinator-habitat-installation-guides/.

*Corresponding author.

E-mail address: chrismateru@ yahoo.com 